\title{
Population Genetics and Phylogeography of Bigeye Tuna in Moluccas Seas, Indonesia
}

\author{
Nebuchadnezzar Akbar ${ }^{1 *}$, M. Irfan² and Muhammad Aris $^{2}$ \\ ${ }^{1}$ Marine Science Departement. Faculty of Marine Science and Fisheries, Khairun University \\ Jl. Pertamina Kampus II Unkhair Gambesi Kota Ternate Selatan \\ ${ }^{2}$ Aquaculture Departement, Faculty of Marine Science and Fisheries, Khairun University \\ Jl. Pertamina Kampus II Unkhair Gambesi Kota Ternate Selatan \\ Email: nezzarnebuchad@yahoo.co.id
}

\begin{abstract}
The bigeye tuna (Thunnus obesus) is a migratory fish which can be found in the Atlantic, Indian and Pacific oceans. This fish has a commercial value and has been exploited worldwide including in Indonesia. The exploitation might affect the genetic diversity and population structure. The fact that the population stock resource is abundant and following fishing activities are increasing, study on population genetic and phylogeography canbe used as information to determine the status of the fish population based on genetic data. The study was conducted to investigate population genetic, and phylogeography of bigeye tuna in the North Moluccas and South Mollucas Seas, Indonesia. A total of 60 tissue bigeye tuna samples were collected from two study sites. The samples were amplified using mitochondrial DNA control region. Within population genetic diversity was revealed of 0.985 and 1.00 in North Moluccas and in south Moluccas, respectively, while between populations was 0.989. The genetic distance within population of North Moluccas (0.029) and South Mollucas (0.24) was very low, and all population was 0.027. The genetic distance between population of North Mollucas and South Mollucas was 0.025 , South Mollucas and all population was 0.023 , and all population with Norht Mollucas was 0.027. The genetic distance of North Mollucas and Pacific Ocean was 0.029, South Mollucas and Pacific Ocean was 0.023, North Mollucas, South Mollucas and Indian Ocean was 0.32. The Fst value between populations (0.990) showed that the two populations were not genetically different. A similar result showed from the phylogenetic trees analysis which individual of bigeye tuna was randomly clustred between North Moluccas and South Mollucas population, indicating that they were genetically close and from the same population. The population bigeye tuna from the North Mollucas and the South Mollucas exhibits no apparent phylogeographic distribution.
\end{abstract}

Keywords: Thunnus obesus, phylogeography, haplotype, fixation index

\section{Introduction}

Bigeye tuna (Thunnus obesus) is an important tuna species found in the Atlantic Ocean, Indian Ocean and Pacific Ocean (Bremer et al., 1998). Bigeye tuna are migratory fish which have a commercial value (Chiang et al., 2008). Bigeye tuna has pointed out the increasing concerns on the bigeye tuna stock status due to worldwide overfishing in recent years (ICCAT 2005). The high commercial value makes this fish as the target fish in any fishing operation. This has brought about a view of the necessity to study the population genetic structure, aiming at the sustainability and effectiveness of resource management (Nishida et al., 1998; Chiang et al., 2006; Chiang et al., 2008).

Fishing of tuna operations in Pacific Ocean have been done from 1950 until now and tuna fishing has been increasing over time (Sibert et al., 2009). Total production potential has reached 1000 tons. $y^{-1}$ and total catch production in Pacific Ocean from 1950 until 2000 years reached 50 million tons. $y^{-1}$ and the value of tuna sales until 2008 was estimated at U.S. \$ 5 billion (Sibert et al., 2009; Williams and Terawasi 2009). Previous studies revealed that the global bigeye tuna population consisted of two clades (Bremer et al., 1998; Chow et al., 2000; Appleyard et al., 2002; Durand et al., 2005; Martınez et al., 2006; Chiang et al., 2006). Both clades existed in all three oceans with significantly different distribution frequencies between the Atlantic and the Indo-Pacific Oceans. Clade I was the dominant clade in the Indo-Pacific Ocean, contributing to $90 \%$ of its population, while Clade II was the main clade of the Atlantic Ocean, making up $73 \%$ of its population (Bremer et al., 1998). 
Research on population structure focusing on fish genetic diversity in Indonesia has been carried out by a number of researchers among others, a study of the variation genetics of yellowfin tuna ( $T$. albacores) in Bali, North Moluccas and North Celebes seas (Permana et al., 2007). They were found genetic variation yellowfin tun was was 0.857 . Suman et al., (2013) study about bigeye tuna level genetic diversity found was 0.8267 in Indian Ocean at western part of Sumatra and southern part of Java and Nusa Tenggara. However, The Information about the population structure of bigeye tuna in the waters of North Maluccas and South Mollucas unexplored until now. The waters North Moluccas and South Mollucas, which have long been known as migration area and the most productive fishing ground area in Indonesia, have a great potential for tuna fishing (Ministry of Marine Affairs and Fisheries 2011). Total production of tuna fishing in 2011 was 106.5 tons. $y^{-1}$ and the fishing production in Ambon reached 104.12 tons. $y^{-1}$ (Ministry of Marine Affairs and Fisheries 2011).

The availability of bigeye tuna ( $T$. obesus) in the waters of North Mollucas and South Mollucas is followed by the increase in the fishing activity. Despite the fact that studies have been performed on the bigeye tuna population structures, none was undertaken regarding the bigeye tuna population Moluccas seas. Based on the fact that these regions are important fishing grounds, studies of the bigeye tuna population structure in these areas will help enhance management and conservation of the fishery. Genetic diversity is very important in the stability and security of the population (Ferguson et al., 1995).

The method used to determine genetic information was PCR sequencing technique, which could be employed to obtain the sequence of nucleotide bases in a DNA molecule (Sanger et al., 1977). In addition, this technique is very easy, fast, efficient (Ubadillah and Sutrisno. 2009; Graham and Hill 2001). DNA sequencing methodology that became known as Sanger sequencing, based on enzymatic synthesis from a single-stranded DNA template with chain termination using dideoxynucleotides (ddNTPs) (Graham and Hill, 2001). This method has been used in research Martinez (2006) and Chiang et al. (2008).

This paper investigates population genetic and phylogeography of Bigeye Tuna in Mollucas seas, Indonesia for management purpose and future stock assessment.

\section{Material and Methods}

Bigeye tuna ( $T$. obesus) samples were collected from North Moluccas sea $(n=40)$ and South
Moluccas sea $(n=20)$ by scientific observers from commercial fishing vessels from January to Mei 2016 (Figure 1.). Muscle tissue specimens were fixed in $95 \%$ ethanol and frozen at $-20^{\circ} \mathrm{C}$ until DNA extraction Additional mitochondrial DNA sequence data of Bigeye Tuna from the Pacific $(n=20)$ and Indian Ocean $(n=20)$ were used to compare the four population. All sequence data downloaded from GenBank with accession number available (Table 1.).

\section{DNA extraction, PCR and sequencing}

The DNA isolation was conducted with $10 \%$ Chelex solution following protocol of Walsh et al. (1991). Amplification was conducted at the locus mtDNa control region using primer forward CRK 5'AGCTC AGCGC CAGAG CGCCG GTCTT GTAAA-3' and primer reverse CRE 5'-CCTGA AGTAG GAACC AGATG3' (Lee et al., 1995). Polymerase Chain Reaction (PCR) used applied biosystem (AB) machine for reaction was performed in a total volume of $25 \mu \mathrm{L}$ contained $2.5 \quad \mu L 10 x$ PCR buffer (Applied Biosystems), $2.5 \mu \mathrm{L} 10 \mathrm{dNTPs}, 1.25 \mu \mathrm{L}$ of each primer at $10 \mathrm{mM}, 2 \mu \mathrm{L} 25 \mathrm{mM} \mathrm{MgCl} 2$ solution, $0.125 \mu \mathrm{L}$ AmplyTaq Red ${ }^{\mathrm{TM}}$ (Applied Biosystems), 1 $\mu \mathrm{L} 1 \mathrm{x}$ BSA and $13.5 \mu \mathrm{L} d d H 20,1 \mu \mathrm{L}$ DNA template. PCR profile included an initial denaturation at $94^{\circ} \mathrm{C}$ for $15 \mathrm{sec}$, 38 cycles covering denaturation at $94^{\circ} \mathrm{C}$ for $30 \mathrm{sec}$, annealing at $50^{\circ} \mathrm{C}$ for $30 \mathrm{sec}$, and extension at $72^{\circ} \mathrm{C}$ for $45 \mathrm{sec}$, and at $72^{\circ} \mathrm{C}$ for $5 \mathrm{~min}$. The quality of PCR product were tested in electrophoresis (1\% agarose, $100 \mathrm{~mL}$ TEA, and 4uL EtBr) PCR product (Sanger et al., 1977).

\section{Data analysis}

Genetic population analyses were performed using Arlequin 3.5 (Excoffier dan Lischer 2009) and DnaSP 4.0 (Rozas et al., 2003) based on mitochondrial control region DNA sequence data. Descriptive statistics such as the haplotype diversity (Hd; Nei, 1987), nucleotide diversity (Nei, 1987) (everage $=0.00-1.00)$ and the average number of pairwise nucleotide differences ( $k$; Tajima, 1983) were determined for each geographic population using DnaSP 4.0. The inter-haplotype levels of divergence were estimated using the fixation indexFst (everage $=0.00-1.00$ ) with number permutation 100 and significant level 0.05 (Excoffier et al., 1992) with Arlequin 3.5, which includes information on genetic distances (Tamura and Nei, 1993) with MEGA5. Estimation of phylogeny tree reconstructed using neighbor-join and evolution model of Kimura 2parameter (Satiou and Nei, 1987) in MEGA5 (Tamura et al., 2011). Genetic distance analysis is a representation that shows how big the difference in the two populations is in terms of genetic. It shows overall significant levels of genetic distance in and among population bigeye tuna collections. 


\section{Result and Discussion}

\section{Genetic diversity}

The Total number of samples bigeye tuna 60 individuals were observed, 56 haplotypes and 519 bp (base pairs) in control reagion locus were defined (Table 2.). Most of the haplotypes were unique to particular individuals and 56 haplotypes were unique and the 3 haplotype was found in three individuals (one haplotype each from North Mollucas and South Mollucas population). In North Mollucas population bigeye of 40 individuals were analyzed 37 different haplotypes were found scattered on each individual and foun 3 haplotypes were distributed in the same two individuals (haplotypes 24, 35 and 56). The location of South Mollucas found 19 different haplotypes and distributed to each individuals (1 haplotypes distributed on 2 different individuals the location of North Mollucas and South Mollucas). The research result supported Martinez et al. (2006) were found a total 222 different haplotype of 256 samples bigeye tuna in Atlantic Ocean. Similarity, between the research showed that distributed haplotypes highly and significant indices gen variation in population differentiation and caused by genetic mating between populations that result in gen flow. Durand et al. (2005) reported that unidirectional gene flow of the bigeye tuna populations from the Indo-Pacific Ocean to the Atlantic and their admixture off southern Africa. The reported support by Gonzalez et al. (2008) wer found unrestricted gene flow bigeye tuna in Atlantic Ocean consequence marriages occour between different populations. In this study reported that medley mark of haplotype indicated that the bigeye tuna population especially group of sample in North
Mollucas and South Mollucas was categorized as low disturbance stock. These assumption same as Suman et al. (2013) reported that sample in south off Java and Nusa Tenggara was categorized as low disturbance stock and had medley mark of haplotype.

This study showed high levels of both the haplotype and nucleotide diversities within and between population bigeye tuna (table 1), similar to those reported for other population bigeye tuna in another regional (Martınez et al., 2006; Chiang et al., 2008). Martinez et al. (2006) with their result in Atlantic Ocean of bigeye tuna found that haplotype level was 1.00 and nucleotide diversities was 0.031 . Its similar reported Chiang et al. (2008) were found highly level haplotypes diversities (0.999) and nucleotide diversities (0.043) in Western Pacific Ocean. In addition, bigeye tuna haplotype diversity of the both population in Mollucas Sea (0.997) was same as of other regional populations (Martinez et al., 2006 in Atlantic and Chiang et al., 2008 of Southeastern Indian Ocean) (about 0.998). The haplotype diversity of bigeye tuna population in North Moluccas was 0.996 , the value of the nucleotide diversity was 0.028 and haplotype diversity of bigeye tuna obtained in South Moluccas was 1 and the nucleotide diversity was 0.036 . The haplotype diversity of bigeye tuna between the two populations 0.997 and the nucleotide diversity was 0.026 (Table 2.). In this resulted, which were similar to those reported for other highly migratory pelagic fishes (Bremer et al., 1997, 2005; Carlsson et al., 2004). The genetic diversity tuna showed when compared with other marine diversity fish such as Anggoli fish 0.417 (Wigati et al., 2003), Lutjanus sebae 0.099 (Permana et al., 2003), reef fishes (Families
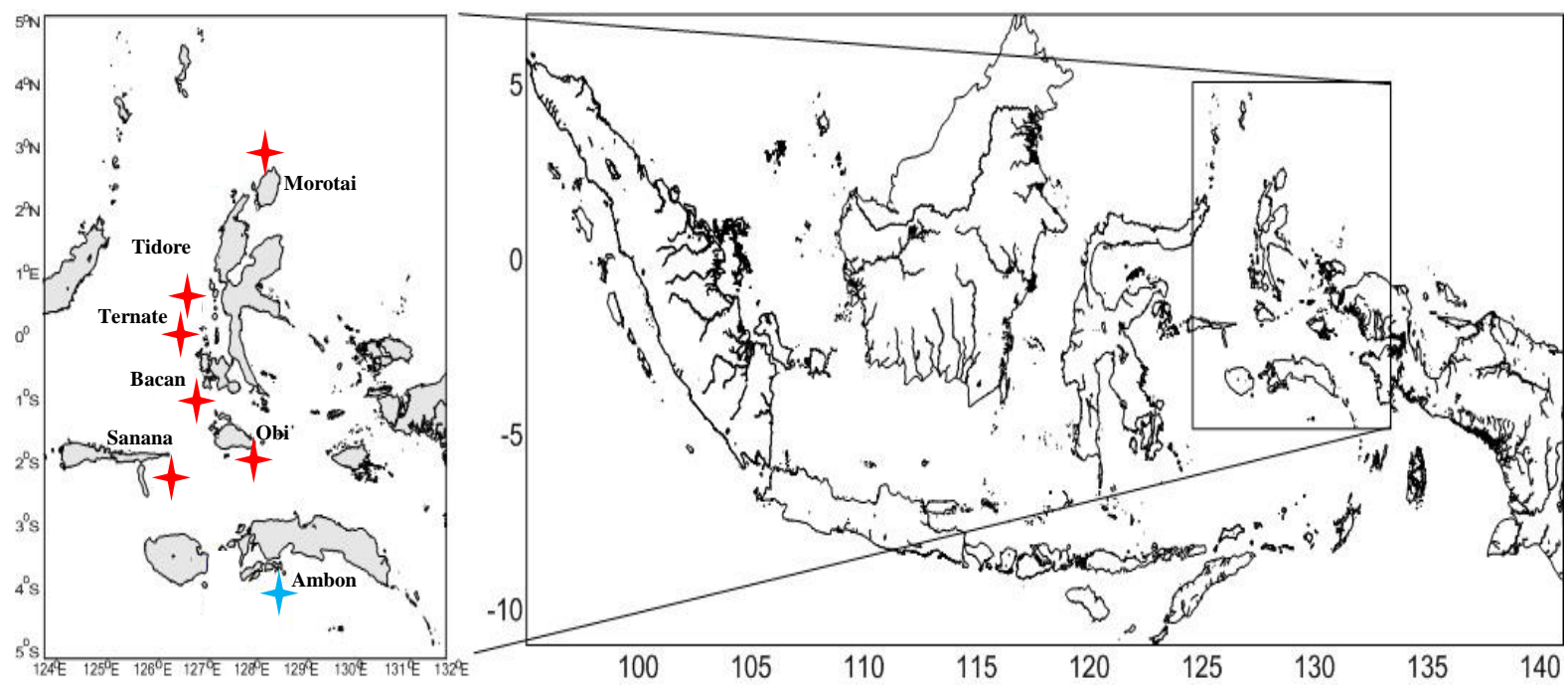

Figure. 1. Map of the bigeye tuna (Thunnus obesus) sampling location and region in Indonesia. (red stars = North Mollucas, blue stars $=$ South Mollucas) 
compared with other fish that live in group and relative certain region and ability to be a low Pomacanthidae and Chaetodontidae) 0.467 (Affonso and Galetti, 2007), humpback grouper 0.774 (Sembiring et al., 2013). Differences in genetic diversity may be caused the nature of migration and spread of higher tuna and clustered so as to provide opportunities to meet with other population groups, migration. These assumption supported (Grant, 1985; Wild, 1994) that the rate of migration of wild tuna are higher than other marine fish led to a meeting and crossing opportunities genes with other populations greater. The low of haplotypes diversity for Mediterranean samples have also been reported in swordfish (Rosel and Block 1996; Chow et al., 1997; Bremer et al., 1998). Similarity and difference in value due to the amount used varies, Nei (1981) explained that genetic diversity of a species depend on size of the samples is found. This situation might be explained by three different. First, the populations of bigeye tuna have not been disturbed by the exploitation activities. However, since exploitation is happening in this site so this first assumption might not work. Second, other populations originating may positively affect in terms of the mating occurrences among the populations, increasing the genetic variation within the populations. Third, the factor of high migration ability will lead to meetings among a large population, bringing about the mating occurrences of different populations (interpopulation variability). This assumption similar to Chiang et al. (2008) that bigeye tuna population is generally large and widely distributed throughout the world, may account for the high level of haplotypic diversity observed in this study. Haplotypes diversity was also high with the majority of haplotypes sampled only once, a typical pattern of scombroid fish (Zardoya et al., 2004). Populations with high genetic diversity have a better chance of survival because each gene has a different response to environmental conditions (Yusron, 2005). Lower mark of genetic diversity would cause negative impact such as the decrease of growth, size diversity, organ development stability, degree of life, and environment adaptation (Leary et al., 1985).

\section{Population genetic}

Mean pairwise uncorrected distances between population bigeye tuna North Mollucas and South Mollucas was 0.025 , and that population bigeye tuna North Mollucas and all population was 0.027 and population bigeye tuna South Mollucas and all population was 0.0236 (Table 3.). Based on the genetic distance obtained, there was closeness and similarity found between the two populations the results explained that the two populations were genetically similar. The genetic closeness was probably due to gene flow between the two populations. It has been reported that genetic differentiation is generally low among bigeye tuna populations within and between oceans (Bremer et al., 1998; Grewe and Hampton 1998; Chow et al., 2000; Appleyard et al., 2002; Durand et al., 2005; Martinez and Zardoya, 2005; Martinez et al., 2006; Chiang et al., 2006; Chiang et al., 2008; Suman et al., 2013). The analyzed in another tuna species has been reported, for example, population genetic studies on mtDNA of Pacific yellowfin revealed very low levels of genetic differentiation (Scoles and Graves 1993; Ward et al., 1994; Ward et al., 1997; Appleyard et al., 2001; Ely et al., 2005).The overall result obtained give an explanation that bigeye tuna that are spread throughout the region have close genetic distance between one another. These statement supported Michels et al. (2001) that population in the same species are separated geographically dispersed and have a relationship structure and gen flow among population scattered.

There are two indications that enable the genetic similarity and proximity between the two populations. The first indication, the group of the North Mollucas population was probably trying to migration the waters of Seram Sea before meeting with other populations in the Banda waters. The second indication, the second group of the population is a group in the waters which migrate and mate, allowing the occurrence of gene flow between the two populations. This indicated support by Lee et al. (2005) stated that the distribution pattern

Table 1. Accession number In Genbank of sequence mitochondria DNA control region of 40 individual bigeye tuna (T.obesus) from Pacific and Indian Ocean.

\begin{tabular}{ll}
\hline Location & Accesion Number \\
\hline Indian Ocean & DQ126521, DQ126524, DQ126528, DQ126530, \\
& DQ126533, DQ126536, DQ126545, DQ126555, \\
Pacific Ocean & DQ126562, DQ126523, DQ126527, DQ126529, \\
& DQ126541, DQ126544, DQ126547, DQ126550, \\
& DQ126558, DQ126561, DQ126535, DQ126534. \\
& DQ126589, DQ126586, DQ126582, DQ126578, \\
& DQ126593, DQ126581, DQ126571, DQ126599, \\
& DQ126587, DQ126585, DQ126574, DQ126577, \\
& DQ126591, DQ126575, DQ126588, DQ126598, \\
& DQ126568, DQ126576, DQ126603, DQ126583. \\
\hline
\end{tabular}


Table 2. Moleculer characterics of bigeye tuna (T.obesus) from Moluccas Seas ( $\mathrm{n}$ : number of sample, H: number of haplotypes, $H_{d}$ : haplotypes diversity, $\Pi$ : nucleotide diversity)

\begin{tabular}{|c|c|c|c|c|c|}
\hline Population & Location & $N$ & $H$ & $H_{d}$ & $\Pi$ \\
\hline North Moluccas & $0^{\circ} \mathrm{S}-126^{\circ} \mathrm{E} ; 2^{\circ} \mathrm{S}-127^{\circ} \mathrm{E}$ & 40 & 37 & 0.996 & 0.028 \\
\hline South Mollucas & $2^{\circ} \mathrm{S}-127^{\circ} \mathrm{E} ; 4^{\circ} \mathrm{S}-127^{\circ} \mathrm{E}$ & 20 & 20 & 1 & 0.036 \\
\hline All Population & $0^{\circ} \mathrm{S}-126^{\circ} \mathrm{E} ; 4^{\circ} \mathrm{S}-127^{\circ} \mathrm{E}$ & 60 & 56 & 0.997 & 0.026 \\
\hline
\end{tabular}

of bigeye tuna in the Indian Ocean has similarity to that of bigeye tuna from the Pacific Ocean. The value of genetic distance obtained was supported by the phylogenetic tree due to the mixing between the two populations. Martinez et al. (2006) reported that physical constraints has caused the two fishes to be separated and not associated with fish besides migration which also affects the genetic variation. No differences were found in the frequencies of these two lineages between the two regional populations.

The Fst value showed that the genetic differences between the populations of bigeye tuna ( $T$. obesus) between North Mollucas and South Mollucas were not significant with analysis compute pairwise differences (Table 4.). This illustrates that the bigeye tuna populations from population are the same population. This analysis strengthens the assumption that bigeye tuna populations of the two locations from was same population. In this study comparison bigeye tuna population North Mollucas, South Mollucas with the Pacific Ocean and Indian an taken in Genbank which have been reported by (Martinez et al., 2006). The current study found that our genetic sample detected show that more closennes in Pacific Ocean than Indian Ocean. Our evidence of no population structuring in the Indian Ocean was concordant with nuclear evidence based on microsatellite data (Appleyard et al., 2002). The Result study same as reported (Bremer et al., 1998; Martinez et al., 2006; Chiang et al., 2006: Chiang et al., 2008; Suman et al., 2013) that population of bigeye in the Indian and Pacific Ocean was low destrictied genetic than Atlantic. Chiang at al. (2008) reported that lack of genetic structure demonstrated extensive gene flow within the Indo-Pacific Ocean than Atlantic Ocean.There have been two mtDNA genetic analyses carried out by the PCR-sequencing method on the bigeye tuna population structure (Martınez et al., 2006; Chiang et al., 2008). Despite the methods used, all these studies showed that same phylogenetic built up the bigeye tuna population structure.

Pairwise analysis (Fst) tested comparisons of North Mollucas, South Mollucas and Pacific Ocean populations were not significant. The final result value of Fixation index (Fst) were found between the three population support the notion that bigeye tuna population derived from the Pacific Ocean.

\section{Phylogeography}

The mtDNA phylogeography suggests that based on the result of the phylogenetic tree analysis of bigeye tuna ten groups of population were found (including Pacific and Indian Ocean) (Figure 2.). The first clade was a mixture of bigeye tuna population between three South Moluccas individuals, nine North Moluccas individuals, seven Pacific Ocean individuals, and two individuals from Indian Ocean. The second clade two North Moluccas individuals, three South Moluccas individuals, three Pacific Ocean individuals, and two individual from Indian ocean. The third clade consisted was one individual Pacific, Indian Ocean and South Mollucas. The fourth clade dominated by four individuals North Mollucas. The five clade a mixture of five North Moluccas individuals, three South Moluccas individuals, one individual Pacific Ocean and one Indian Ocean indiviudal. The sixth clade was four North Moluccas, two Indian Ocean individuals, and one Pacific Ocean individual. The seventh clade consisted of five North Moluccas individuals, seven South Moluccas individuals, four individuals Pacific Ocean, and five individuals Indian Ocean. The eigth clade consisted of three North Moluccas individuals, and one of Pacific Ocean individual. The ninth clade one individual from North Mollucas, two South Mollucas individuals, six individuals from Indian Ocean, and one individual from Pacific ocean. The tenth clade consisted by five from North Mollucas individuals and one individual from South Mollucas. The using reconstructed Neigbor-joining phylogeny using with a gamma value of 5 and booktstrap replication 1000 of bigeye tuna is shown in (Figure 2.). Within each clade, phylogenetic relationships lacked bootstrap support, and apparent relationship between haplotypes from the same geographic area was detected. The Phylogenetic reconstructions were made to support the result of the genetic distance analysis and fixation index (Fst), which shows that both population have a genetic distance adjacent. So we can conclude that population derived from the same lineage.

Phylogenetic tree mitochondrial control region sequence data confirm that tenth clade and not restricted with population bigeye from North Mollucas, South Mollucas, Pacific and Indian Ocean. It similar to those reported that phylogenetic tree 
from individuals same is generally form one Clade (Chiang et al., 2006; 2008; Marinez et al., 2006). The final result of Chiang et al. (2006) show that intermixture between population bigeye tuna in the South China Sea, Philippine Sea and western Pacific Ocean. Overall tested of Chiang et al. (2008) found that phylogenetic tree in Indian Ocean were mixture (incuded Guinea of the Atlantic Ocean and Western Pacific Ocean) and the likewise Martinez et al. (2006) where their found population bigeye in Atlantic Ocean (Gulf of Guinea, Canary Islands, Azores and Canada) not restricted and mixture. Even distribution of each sampling area specimens showed no apparent geographic structuring between haplotypes in overall clade (Figure 3.). In addition, the results of neighborjoining tree network reveal both populations in our location study divergent lineages that are evenly distributed in all sampling regions. In summary, these genetic data indicate panmictic bigeye tuna population in the Mollucas Sea and that this panmictic population appears to contain two divergent same. Previous population genetic studies revealed that a single stock of bigeye tuna exists in the Indo-Pacific Ocean (Bremer et al., 1998; Durand et al., 2005; Martinez et al., 2005).

Network distribution of haplotypes showed mixing occurred different individuals and all network locations haplotype spread to the entire network, thus fail to show grouping, or clade between different geographical locations (Figure 2.). We observe that mtDNA haplotypes predominantly distributed throughout sample possessed. What's more, haplotype distribution followed by a very high FST values and there is mixing between haplotypes. All of this suggests that the tuna North Mollucas and South Mollucas compared to samples of tuna from the
Indian and the Pacific Ocean are the population "panmixia" or mixing. The observed heterogenity in the population North Mollucas and South Mollucas is similar bigeye tuna caught from different oceans (Chiang et al., 2006; Santos et al., 2010; Suman et al., 2014). "Mixing Population" of the species in the region is very possible because of the high mobility of the species, the play of the prevailing currents and accompanying larval dispersal (Wyrtki, 1961). Distribution bigeye tuna on overall sea including Pacific Oceans, Mollucas Sea, Halmahera Sea and Seram Sea until Samudera Ocean indicated that hight pattern migration. Bailey et al. (2012) and Baskoro et al. (2004) reported that several distributions species tuna; yellowfin tuna (Thunnus albacares), bigeye tuna (Thunnus obesus), skipjack (Katsuwonus pelamis), alalunga tuna (Thunnus albacore) dan tatihu tuna (Thunnus maccoyii) in Indonesia Sea. The fishery targets four primary temperate and tropical tuna species: skipjack (Katsuwonus pelamis), yellowfin (Thunnus albacares), bigeye (T.obesus), and albacore ( $T$. alalunga) tuna (Sibert et al., 2009). Graves (1996) suggested that several pelagic fishes like skipjacks, albacore, bigeye tuna and yellowfin tuna fishes have exhibited little spatial partitioning within and between ocean basins because of the occurrence of continuous. Tunas in particular have also been suggested by Ward (1995) to exhibit a low population divergence and that migration of just a few individuals per generation could produce neargenetic homogeneity.

The resulting phylogenetic tree is supported by the genetic distance analysis in Mollucas seas (included Pacific and Hindia Ocean) (Table 6.). Analysis genetic distance found that population

Table 3. Genetic distance of bigeye tuna (T.obesus) populations based on DNA mitochondrial control region sequence data

\begin{tabular}{|c|c|c|c|c|}
\hline Genetic distance & Location & North Mollucas & South Mollucas & All Population \\
\hline \multirow[t]{3}{*}{ In population } & North Mollucas & 0.029 & - & - \\
\hline & South Mollucas & - & 0.024 & - \\
\hline & All Population & - & & 0.027 \\
\hline \multirow[t]{3}{*}{ Between population } & North Mollucas & - & 0.025 & 0.027 \\
\hline & South Mollucas & - & - & 0.023 \\
\hline & All Population & - & - & - \\
\hline
\end{tabular}

Table 4. Bigeye tuna (T.obesus) population analysis based on paired distance method (Fst)

\begin{tabular}{llllll}
\hline Structure tested & Location & NM & SM & IO & PO \\
\hline Bigeye tuna & NM & - & 0.990 & 0.243 & 0.833 \\
& SM & - & - & 0.253 & 0.909 \\
& IO & - & - & - & 0.255 \\
& PO & - & - & - & - \\
\end{tabular}

\footnotetext{
* NM; North Mollucas, SM; South Mollucas, IO; Indian Ocean, PO; Pacific Ocean
} 
bigeye tuna North Mollucas with South Mollucas was 0.027, North Mollucas and Pacific Ocean was 0.29, North Mollucas and Indian Ocean 0.32, South Mollucas and Pacific Ocean was 0.023 , South Moluccas and Hindia Ocean was 0.32, and than Pacific and Hindia Ocean was 0.027. Presentation explaining the velue of genetic distance that bigeye tuna population give more influence to the population genetic in Mollucas Sea, it can be happen because the two site closer to Pacific Ocean and cal also be based on the ablity of migration owned fish tuna. Other research about phylogeography tuna has been reported (Bremer et al., 2005; Wu et al., 2010). These result $\mathrm{Wu}$ et al., (2010) suggested that yellowfin tuna in the Western Pacific and the Western Indian Oceans exhibits no genetic differentiation in geographic distributions, whereas Bremer et al., (2005) found that in spite of the discordant phylogenetic and phylogeographic signals, the demographic history of Atlantic swordfish and Atlantic bluefin tuna suggests concordance in the timeline of population expansion. A phylogeographic study of five commercially important pelagic fishes (Jackson et al., 2014).

Genetic distance and relationship among group of samples (phylogeny) of big eye tuna in two Mollucas sea was 0.027 (Table 3. and Figure 2.). Genetic distance test of North Mollucas versus South Mollucas showed no statistically significant genetic structuring. These result support phylogeography which showed the similarities between both populations in Mollucas Sea. The small level of divergence in two population Mollucas sea is attributed the low level of divergence is attributed a secondary contact between previously panmictic lineages. In this study, some studies have also reported which reported that no spatial distance genetic in their study sites such as Chiang et al., 2006 (South China Sea, Philippine Sea and western Pacific Ocean); Chiang et al., 2008 (Indian Ocean); and Sumat et al. (2013) (Indian Ocean at Western part of Sumatra and Southern part of Java and Nusa Tenggara, Indonesia). Bremer et al. (2005) explained

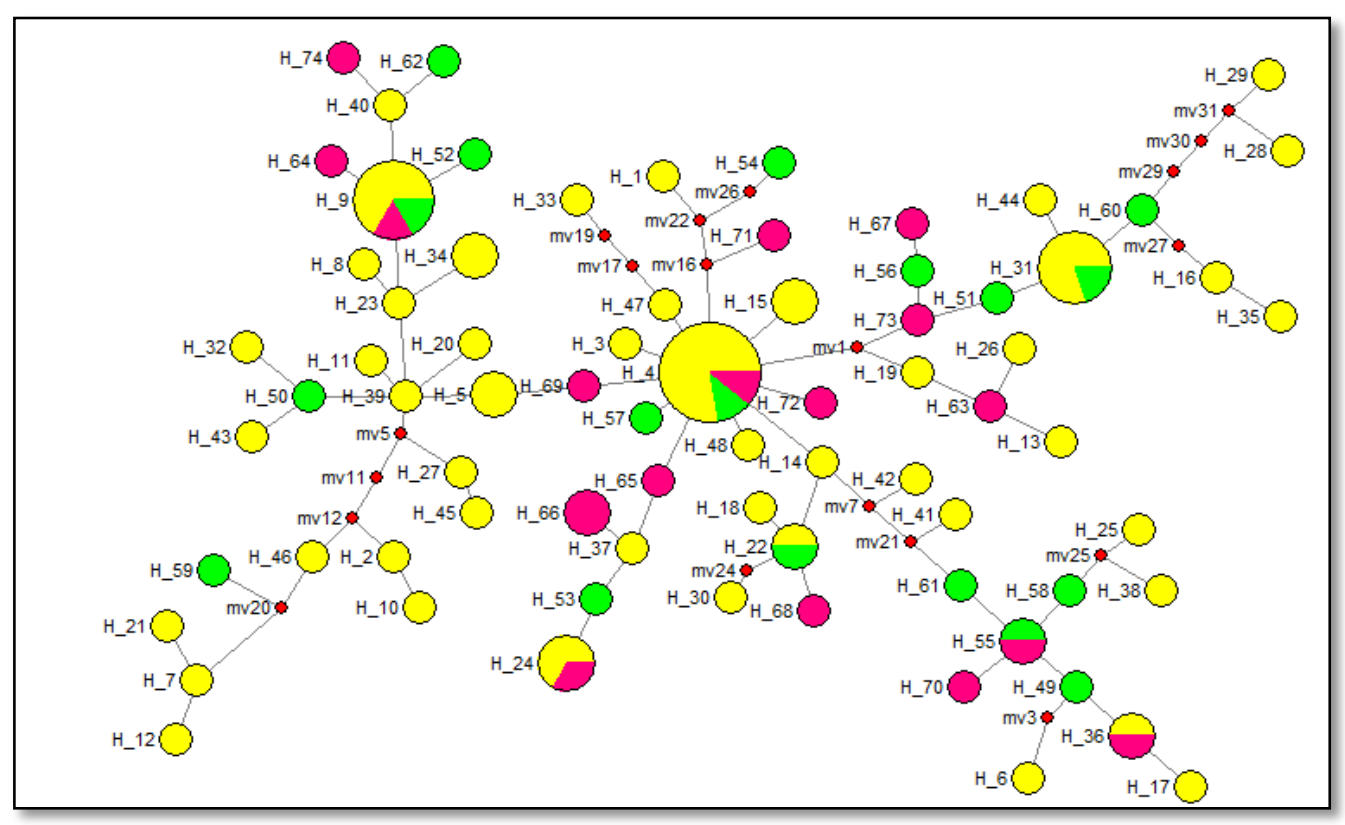

Figure 2. Haplotype networks for bigeye tuna (Thunnus obesus) in Mollucas Sea and Hindia and Pacific Ocean (secondary data). (Mollucas Sea = yellow circle, Pacific Ocean = pink circle and Indian Ocean = green circle).

Table 5. Bigeye tuna (T.obesus) population analysis based on genetic distance

\begin{tabular}{ccccc}
\hline Location & PO & IO & NM & SM \\
\hline Pacific Ocean & - & & & \\
Indian Ocean & 0.027 & - & - & 0.32 \\
North Mollucas & 0.029 & 0.32 & 0.027 & - \\
South Mollucas & 0.023 & 0.327 & \\
\hline
\end{tabular}

* NM; North Mollucas, SM; South Mollucas, IO; Indian Ocean, PO; Pacific Ocean 
that comparative phylogeography has revealed remarkable patterns of concordance in the maternal phylogenies of many species.Phylogeography study about tuna and mackerel have also shown reinforcing lineage divergence in the Indonesian Archipelago (Jackson et al., 2014), this study found that divergence dates of all pelagic fish lineages dated to the Pleistocene epoch. Concordant barriers to larval dispersal found near Sumatra, Sulawesi, and Papua suggested that the Halmahera and Mindanao eddies and the Indonesian flowthrough may be contemporary forces maintaining genetic divergence between demes of pelagic fishes.

Although based on the geological history the North Moluccas Island chain never united with other islands like Celebes Island and Papuan Island (Setiadi and Hamidy 2006), this did not affect the genetic distribution. Instead, enabled bigeye tuna to influence the process of genetic transfer between populations due to its high mobility. The geographical position of the two locations which is not so far apart presents were 424 mile a chance of genetic similarity. In addition, a large population and high migration capability in the waters caused the absence of the distance influence on the genetic value of the two populations. Based on the two studies above, it can be concluded that geographical distance does not give significant influence on a large amount of fish population with high migration capability. Several explanations including the occurrence of sufficient inter and intra oceanic gene flow (Scoles and Graves 1993; Ward et al., 1997), the insufficient time duration since population expansion (Ely et al., 2005), the large population sizes and the wide distribution of marine fishes throughout the world (reviewed in Avise 1998; Chiang et al., 2006, 2008) were proposed to account for this observation.

The phylogeography study supported the results obtained and gave the notion that bigeye tuna populations in North Moluccas and South Moluccas had genetic closeness population Pacific Ocean. The populations in Mollucas Sea were derived from the same lineage. Both locations which are close to each other and are still in the eastern part of Indonesia help to form the phylogenetic tree. Based on the result of observations, it seems likely that the bigeye population from the North Mollucas and the South Mollucas exhibits no apparent phylogeographic distribution.

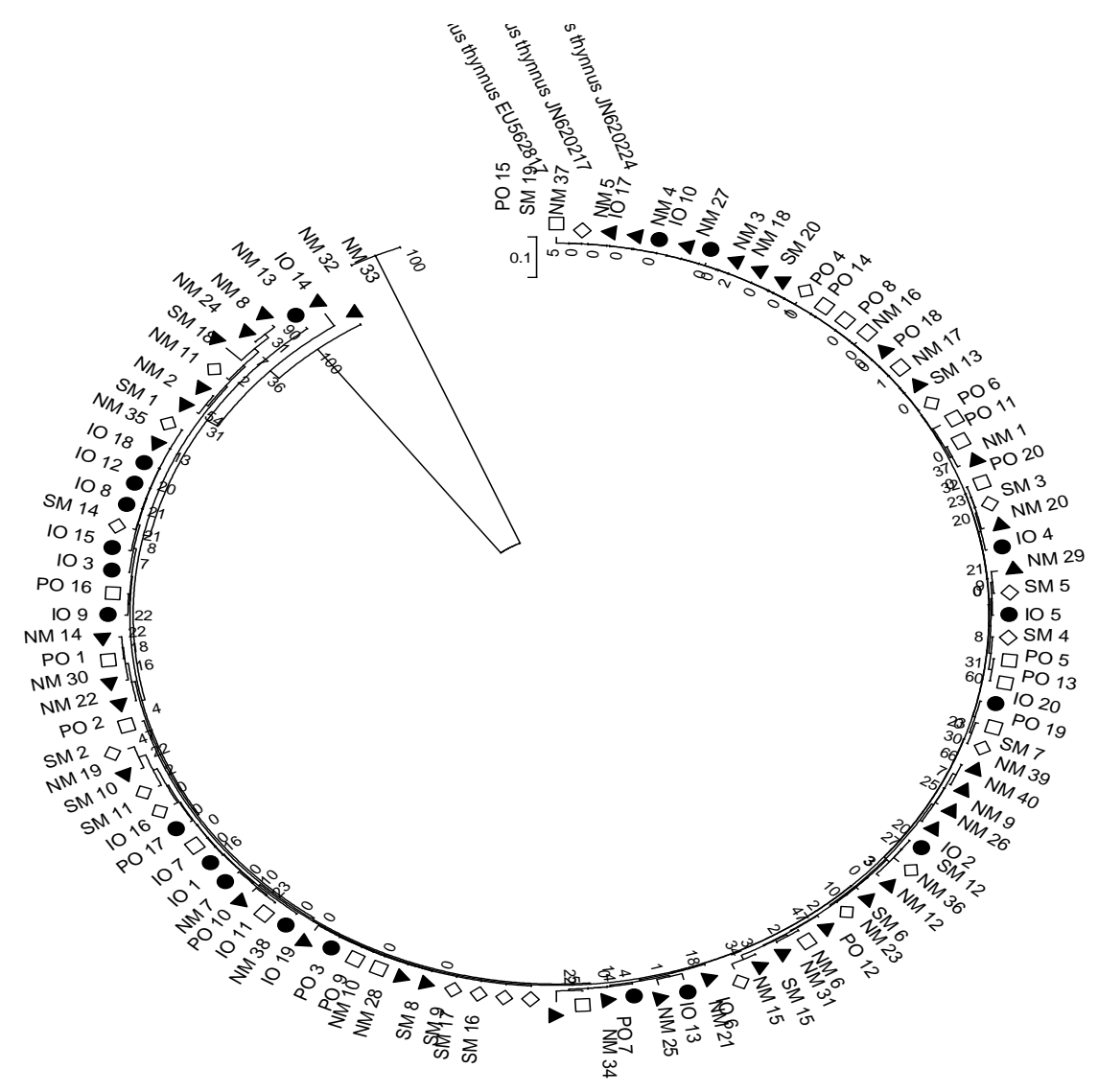

Figure 3. The neighbor-joining tree estimated with the Kimura 2-parameter model among mtDNA lineages of bigeye tuna (Thunnus obesus) collected from the Mollucas Sea (Bold triangle=North Mollucas, diamond=South Mollucas), Indonesia compared with Indian Ocean (Bold circle) and Pacific Ocean (square) 


\section{Conclusions}

In summary, population genetic and phylogeography bigeye tuna ( $T$. obesus) from Mollucas Sea were high diversity, close genetic and from the same populations. Better management is needed in order to keep the stock away from any disturbance so that the decrease of genetic diversity can be avoided.

\section{References}

Affonso, P. \& Galetti, Jr. P.M. 2007. Genetic diversity of three ornamental reef fishes (Families Pomacanthidae and Chaetodontidae) from the Brazilian coast. Braz. J. Biol. 67(4, Suppl.): 925933. doi: 10.1590/S1519-69842007000500 017

Appleyard, S.A., Grewe, P.M., Innes, B.H. \& Ward, R.D., 2001. Population structure of yellowfin tuna (Thunnus albacares) in the western Pacific Ocean, inferred from microsatellite loci. Mar. Biol. 139:383-393. doi: 10.1007/s002270100 578.

Appleyard, S.A., Ward, R.D. \& Grewe, P.M., 2002. Genetic stock structure of bigeye tuna in the Indian Ocean using mitochondrial DNA and microsatellites. Fish Biol. J. 60: 767-770. doi: 10.1111/j.1095-8649.2002.tb01701.x

Avise, J., 1998. Phylogeography. Harvard University Press, Cambridge, MA.

Bailey, M., Flores, J., Pokajam, S. \& Sumaila, U.R. 2012. Towards better management of Coral Triangle tuna. Ocean Coast. Manag. J. 63:30-42.

Baskoro, M.S., Wahyu, R.I. \& Effendy, A. 2004. Distribution and Migration Fish. Bogor Agricultural University. Bogor. Indonesia

Bremer, J.R.A., Stequert, B., Robertson, N.W. \& Ely, B., 1998. Genetic evidence for inter-oceanic subdivision of bigeye tuna (Thunnus obesus) populations. Mar. Biol. 132: 547-557. doi: $10.1007 / \mathrm{s} 002270050420$

Bremer, J.R.A., Vinas, J., Mejuto, J., Ely, B. \& Pla, C., 2005. Comparative phylogeography of Atlantic bluefin tuna and swordfish: the combined effects of vicariance, secondary contact, introgression, and population expansion on the regional phylogenies of two highly migratory pelagic fishes. Molecul. Phylogen. Evol. 36:169 187.

Chiang, H.C., Hsu, C.C., Lin, H.D., Ma, G.C., Chiang, T.Y. \& Yang, H.Y., 2006. Population structure of bigeye tuna (Thunnus obesus) in the South China Sea, Philippine Sea and western Pacific Ocean inferred from mitochondrial DNA. Fish. Res. 79:219-225.

Chiang, H.C., Hsu, C.C., Wu, G.C.C., Chang, S.K., \& Yang, H.Y., 2008. Population structure of bigeye tuna (Thunnus obesus) in the Indian Ocean inferred from mitochondrial DNA. Fish. Res. 90:305-312. doi: 10.1016/j.fishres.2007.11. 006.

Chow, S., Okamoto, H., Miyabe, N., Hiramatsu, K. \& Barut, N., 2000. Genetic divergence between Atlantic and Indo-Pacific stocks of bigeye tuna (Thunnus obesus) and admixture around South Africa. Mol. Ecol. 9:221-227.

Durand, J.D., Collet, A.C., Guinand, B. \& Borsa, P., 2005. Nuclear and mitochondrial DNA markers indicate unidirectional gene flow of Indo-Pacific to Atlantic bigeye tuna (Thunnus obesus) populations and their admixture off southern Africa. Mar. Biol. 147:313-322

Ely, B., Vinas, J., Bremer, J. R.A., Black, D., Lucas, L., Covello, K., Labrie, A.V. \& Thelen, E., 2005. Consequences of the historical demography on the global population structure of two highly migratory cosmopolitan marine fishes: the yellowfin tuna (Thunnus albacares) and the skipjack tuna (Katsuwonus pelamis). BMC Evol. Biol. 5(1):19.

Excoffier, L., Smouse, P.E. \& Quattro, J.M., 1992. Analysis of moleculer variance inferred from metric distance among DNA haplotypes; application to human mitochondrial DNA restriction data. Gen. J. 131:479-491.

Excoffier, L. \& Lischer, H., 2009. Arlequin ver 3.5 user manual; an integrated software package for population genetics data analysis. Swiss Institute of Bioinformatics.

Ferguson, A.J.B., Taggart, P.A., Prodohl, O., Mc Meel, C., Thompson, C., Stone, Mc. Ginnity. \& Hynes, R.A., 1995. The application markers to the study \& conservation of fish population with special referens to salmon. Fish Biol. J. 47:103-126. doi: 10.1111/j.1095-8649.1995.tb06048.x

Graham C.A., Hill A.J.M., 2001. DNA sequencing protocols second edition. Humana Press Totowa, New Jersey.

Grewe, P.M. \& Hampton, J.W., 1998. An assessment of bigeye (Thunnus obesus) population structure in the Pacific Ocean, based on mitochondrial 
DNA and DNA microsatellite analysis. Col. Vol. Sci. Pap. ICCAT, 57(2):3-38.

Graves, J.E. 1996. Conservation genetics of fishes in the pelagic marine realm. In: Conservation Genetics: Case Histories from Nature. Avise JC, Hamrick JL. eds. London, UK: Chapman and Hall. p 335-367.

Gonzalez, E.G, Peter, B. \& Zardoya, R., 2008. Genetic structuring and migration patterns of Atlantic bigeye tuna, Thunnus obesus (Lowe, 1839). BMC Evol. Biol. 8:252.

Jackson, A.M., Ambariyanto, A., Erdmann, M.V., Toha, A. H.A., Stevens, L.A. \& Barber, P.H., 2014. Phylogeography of commercial tuna and mackerel in the Indonesian Archipelago. Bull Mar Sci. 90(1):471-492. doi: 10.5343/bms.20 12. 1097.

Leary, R.F., Allendorf, F.W. \& Knudsen, K.L., 1985. Developmental instability as an indicator of reduced genetic variation in hatchery trout. Transac. Am. Fish. Soc. 114: 230-235. doi: /10.1577/1548-8659(1985)114<230:DIAAIO> 2.0.CO;2

Lee, W. J., Conroy, J., Howell, W.H. \& Kocher, T.D., 1995. Structure and evolution of teleost mitochondrial control reagions. Mol. Evol. J. 41: 54-66.

Lee, P.F., Chen, I.C. \& Tzeng, W.N., 2005. Spatial and temporal distribution patterns of bigeye tuna (thunnus obesus) in the Indian Ocean. Zool. Stud. 44 (2): 260-270.

Michels, E., Cottenie, K., Neys, L., De Gelas, K., Coppin, P. \& De Meester, L., 2001. Geographical and genetic distances among zooplankton populations in a set of interconnected ponds: a plea for using GIS modelling of the effective geographical distance. Mol. Ecol. 10:19291938. doi: 10.1046/j.1365-294X.2001.0134 $0 . x$

Ministry of Marine Affairs and Fisheries, 2011. Marine and Fisheries in Figureures 2011. Jakarta. Indonesia.

Martinez, P. \& Zardoya, R., 2005. Genetic structure of bigeye tuna (Thunnus obesus) in the Atlantic Ocean. Col. Vol. Sci. Pap. ICCAT, 57(1):195-205.

Martinez, P., Gonzales, G.E., Castilho, R. \& Zardoya, R., 2006. Genetic diversity and historical demography of Atlantic bigeye tuna (Thunnus obesus). Mol. Phylogen. Evol. 39: 404-416. doi: 10.1016/j.ympev.2005.07.022
Nei M., 1987. Moleculer evolutionary genetics. New York. Columbia University. Press. Columbia.

Nishida, T., Chow, S. \& Grewe P., 1998. Review and research plan on the stock structure of yellowfin tuna (Thunnus albacares) and bigeye tuna (Thunnus obesus) in the Indian Ocean. IOTC Proceedings No.1. 7th Expert consultation on Indian Ocean tunas, Victoria, Seychelles.

Permana, G.N., Hutapea, J.H., Haryanti. \& Sembiring, S.B.M., 2007. Genetic variation yellowfin tuna (Thunnus albaceras) with electrophoresis allozyme and mtDNA. Aquacul. Res. J. 2(1):4150.

Rozas, J., Sanchez-Del Barrio, J.C., Messeguer \& Rozas R.X., 2003. DnaSP; DNA polymorphism analyses by the coalescent and other methods. Bioinformatics. 19:2496-2497.

Sanger, F., Nicklen, S. \& Coulson, A.R., 1977. DNA sequencing with chain-terminating inhibitors. Proceedings of the national academy of sciences, 74(12):5463-5467.

Santos. M.D., Lopez, G.V. \& Barut, N.C. 2010. A pilot study on the genetic variation of eastern little tuna (Euthynnus affinis) in Southeast Asia. Philippine J. Sci. 139 (1):43-50.

Satiou N. \& Nei, M., 1987. The neighbor-joining method: a new method for reconstructing phylogenetic tree. Mol. Biol. Evol. 4:406-425.

Sembiring, S.B.M., Tridjoko. \& Haryanti., 2013. Genetic diversity humpback grouper (Cromileptes altivelis) F1 and F3 generation. Trop. Mar. Sci. Technol. J. 5(1) 103-111. DOI: 10.29244/jitkt.v5i1.7755

Sibert, J., Hampton, J., Kleiber, P. \& Maunder, M., 2009. Biomass, size, and trophic status of top predators in the Pacific Ocean. Sci. J. 314:17731775.

Scoles, D.R. \& Graves, J.E., 1993 Genetic analysis of the population structure of yellowfin tuna, Thunnus albacares, from the Pacific Ocean. Fish. Bull. 91:690-698.

Suman, A., Irianto, H.E., Amri, K. \& Nugraha, B., 2013. Population structure and reproduction of bigeye tuna (Thunnus obesus) in Indian Ocean at western part of Sumatera and southern part of Java and Nusa Tenggara. Indian Ocean Tuna Commission, 8:1-14.

Tamura, K., Peterson, D., Peterson, N., Stecher, G., Nei, M. \& Kumar S., 2011. MEGA5: Molecular 
evolutionary genetics analysis using maximum Ikehood, evolutionary distance, and maximum parsimony method. Mol. Biol. Evol. 28(10):2731-2739. doi: 10.1093/molbev/msr 121

Ubadillah, R. \& Sutrisno H., 2009. Introduction of biosistematyc: Teory dan Practice. Bogoriense Zoologicum Museum, Biologi Reseacrh Center. Indonesia Institute of Science. Bogor. LIPI Press. Jakarta.

Yusron E., 2005. Utilization of genetic diversity in marine biological resource management. Oseana J. 30(2):29-34.

Ward, R.D., Elliott, N.G., Grewe, P.M. \& Smolenski, A.J., 1994. Allozyme and mitochondrial DNAvariation in yellowfin tuna (Thunnus albacares) from the Pacific Ocean. Mar. Biol. 118: $531-539$

Ward, R.D. 1995. Population genetics of tunas. J. Fish. Biol. 47(Supplement A): 259-280.

Ward, R.D., Elliott, N.G., Innes, B.H., Smolenski, A.J. \& Grewe, P.M., 1997. Global population structure of yellowfin tuna Thunnus albacares, inferred from allozyme and mitochondrial DNA variation. Fish. Bull. 95: 566-575.

Wigati E., Sutarno. \& Haryanti. 2003. Genetic variation anggoli fish (Pristipomoides multidens) based on allozyme banding pattern. Biodiversities J. 4(2):73-79. doi: 10.13057/ biodiv/d040201
Wild, A., 1994. A review of the biology and fisheries for yellowfin tuna, Thunnus albacares, In the eastern Pacific Ocean. FAO Fish. Tech. Pop, 336:52-107.

Williams P., Terawasi P., 2009. Overview of Tuna Fisheries in the Western and Central Pacific Ocean, Including Economic Conditions-2008. Technical Report Western and Central Pacific Fisheries Commission.

Wu, G.C.C., Chiang, H.C., Chou, Y.W., Wong, Z.R., Hsu, C.C., Chen, C.Y. \& Yang, H.Y., 2010. Phylogeography of yellowfin tuna (Thunnus albacares) in the Western Pacific and the Western Indian Oceans inferred from mitochondrial DNA. Fish. Res. 105(3): 248-253. doi: 10.1016/j. fishres.2010.03.015

Wyrtki K. 1961. Physical oceanography of the Southeast Asian waters. Naga report. Vol. 2. Scripps Institution of Oceanography. The University of California. La Jolla. California. $195 p$.

Zardoya, R., Castilho, R., Grande, C., Favre-Krey, L., Caetano, S., Marcato, S., Krey, G. \& Patarnello, T., 2004. Differential population structuring of two closely related fish species, the mackerel (Scomber scombrus) and the chub mackerel (Scomber japonicus), in the Mediterranean Sea. Mol. Ecol. J. 13: 1785-1798. doi: 10.1111/j.13 65-294X.2004.02198.x 